\title{
GROWTH AND YIELD RESPONSES OF SWEET POTATO (IPOMOEA BATATAS) TO TIME OF POTASSIUM FERTILZER APPLICATION
}

\section{C.O. MUONEKE AND E.I. UKPE}

(Received 11 September 2009; Revision Accepted 4, March 2010)

\section{ABSTRACT}

Two field experiments were conducted at the Michael Okpara University of Agriculture, Umudike research farm in 2005 and 2006 wet seasons to determine the growth and yield responses of two sweet potato (Ipomoea batatas L. Lam) varieties viz TIS $87 / 0087$ and TIS 8164 to time of potassium (K) fertilizer application in a humid forest zone of south eastern Nigeria. In 2005 cropping season, the experiment was a $2 \times 4$ factorial laid out in a randomized complete block design with four replications. Potassium $(\mathrm{K})$ treatments comprised no K application, $100 \mathrm{~kg} \mathrm{~K} \mathrm{ha}^{-1}$ at 4 weeks after planting (WAP), $100 \mathrm{~kg} \mathrm{~K} \mathrm{ha}^{-1}$ at $8 \mathrm{WAP}, 50 \mathrm{~K} \mathrm{ha}^{-1}$ at $4 \mathrm{WAP}+50 \mathrm{~K} \mathrm{ha}^{-1}$ at $8 \mathrm{WAP}$. Time of K application had no significant effect on the growth attributes of the varieties, except in tuber dry weight and total dry matter plant ${ }^{-1}$ at 16 WAP where it was higher with split $\mathrm{K}$ application at 4 and 8 WAP in TIS 87/0087. TIS 87/0087 was significantly $(P<0.05)$ higher in total tuber yield when $100 \mathrm{~kg} \mathrm{~K} \mathrm{ha}^{-1}$ was applied at 4 WAP and also with split application at $50 \mathrm{~kg}$ $\mathrm{K} \mathrm{ha}^{-1}$ at $4 \mathrm{WAP}+50 \mathrm{~kg} \mathrm{~K} \mathrm{ha}^{-1}$ at $8 \mathrm{WAP}$. In 2006 cropping season, a 2 x 8 factorial in randomized complete block design with three replications was conducted at the same location as in 2005 . The treatments comprised of no $\mathrm{K}$ application, $100 \mathrm{~kg} \mathrm{~K} \mathrm{ha}^{-1}$ at $2 \mathrm{WAP}, 100 \mathrm{~kg} \mathrm{~K} \mathrm{ha}^{-1}$ at $4 \mathrm{WAP}, 100 \mathrm{~kg} \mathrm{~K}^{-1}$ at $6 \mathrm{WAP}, 100 \mathrm{~kg} \mathrm{~K} \mathrm{ha}^{-1}$ at $8 \mathrm{WAP}, 50$ at 2 $\mathrm{WAP}+50 \mathrm{~kg} \mathrm{Kha}^{-1}$ at $6 \mathrm{WAP}, 50 \mathrm{~kg} \mathrm{~K} \mathrm{ha}^{-1}$ at $2 \mathrm{WAP}+50 \mathrm{~kg} \mathrm{~K} \mathrm{ha}^{-1}$ at $8 \mathrm{WAP}$ and $50 \mathrm{~kg} \mathrm{~K} \mathrm{ha}^{-1}$ at $4 \mathrm{WAP}+50 \mathrm{~kg} \mathrm{~K}^{\mathrm{W}}$ $\mathrm{ha}^{-1}$ at 8 WAP. Tuber and total dry weights were highest when $\mathrm{K}$ was split applied at $4+8$ WAP but lowest when it was applied whole at 8 WAP. TIS $87 / 0087$ was significantly $(P<0.05)$ higher in tuber yield ha- ${ }^{1}$ when $\mathrm{K}$ was split applied at $2 \mathrm{WAP}+6 \mathrm{WAP}$ or $50 \mathrm{~kg} \mathrm{~K} \mathrm{ha}^{-1}$ at $4 \mathrm{WAP}+50 \mathrm{~kg} \mathrm{~K} \mathrm{ha}^{-1}$ at $8 \mathrm{WAP}$. TIS $87 / 0087$ which is a higher yielding variety is recommended for the study area with split application of $\mathrm{K}$ at $2 \mathrm{WAP}+6 \mathrm{WAP}$ or at 4 WAP +8 WAP.

KEY WORDS: Sweet potato, Ipomoea batatas, K, time of K application.

\section{INTRODUCTION}

Sweet potato (Ipomoea batatas) L. Lam) is a widely grown and an important staple food crop in most parts of tropical and subtropical regions of the world and ranked $7^{\text {th }}$ among the world's major food crops (FAO, 2004). Within the sub-Saharan Africa, it is the third most important root and tuber crop after cassava and yam (Hahn and Hozyo, 1998). Of the 45 genera and 100 species in the family Convolvoluceae, only Ipomoea batatas is of economic importance as food (Edmond, 1971).

The increasing potential of the crop in poverty alleviation and food security due to its high productivity per unit area and time makes sweet potato an important crop for the survival of the resource poor farmers in Nigeria (NRCRI, 2003). The crop serves as a starch staple food for human consumption. The tuber can be eaten roasted, fried or boiled (NRCRI, 1985). The foliage and smaller tubers serve as livestock feed (Ambe- Tumanteh, 1994). Its importance in starch, alcohol, pharmaceutical and textile industries is widely recognized (Woolfe, 1992). The orange-fleshed varieties with high $B$-carotene content have become very important in combating vitamin A deficiency, especially in children (Woolfe, 1992). Sweet potato has a high nutritional value and serves as a good source of energy, calcium, iron, vitamins and some minerals (Woolfe, 1992). The leaves are rich in protein, with $34.5 \%$ crude protein (Nwinyi, 1987). Sweet potato roots can be reconstituted into fufu or blended with other carbohydrate flour sources such as wheat and used for baking bread and biscuits (Udoh et al., 2005). However, about $80 \%$ of the crop produced in Nigeria is used for human food (FAO, 2005).

Low soil fertility is one of the constraints in production of sweet potato in Nigeria. In the past, soil had been maintained through long fallow periods (Agboola and Unanma, 1994) but presently, due to population pressure as well as urbanisation and industrialisation, fallow periods have been reduced from 10 years to 1-2 years, resulting in declining crop yield (IITA, 1993). Fertilizer application is an important option left to farmers for yield improvement in most soils. The potential of sweet potato as a cash crop has led to the requirements of fertilizer recommendations for commercial farmers to increase root yield. Continuous cultivation of farm lands leads to depletion of soil nutrients, including K. Successive harvests remove large quantities of $\mathrm{K}$ from the soil and if the element is not sufficiently replaced by fertilization, the soil would be deficient in $\mathrm{K}$.

In sweet potato cultural management, $\mathrm{K}$ fertiliser application has been identified as a factor affecting tuber bulking and yield (Hahn, 1977). Potassium ions promote starch synthesis in tuberous roots. Potassium fertiliser influences tuber quality and plays a significant role in increasing the rate of photosynthesis (Hahn and Hozyo, 1984). Potassium application causes reduction in 
excessive vegetative growth following high nitrogen application (CIP, 1980). Use of $\mathrm{K}$ has also been associated with reduced disease resistance. Jackson et al. (1982) reported reduction in the incidence of stem rot (Erwinia carotovora) with $\mathrm{K}$ fertiliser treatments.

Some work had been carried out on different rates of $\mathrm{K}$ fertiliser to improve tuber yield of sweet potato but research information on time of $K$ application for optimum yield of the crop is scanty. The objectives of the present study being reported were to evaluate the yield of two important sweet potato cultivars under the humid forest conditions and to determine the efficiency of single or split $\mathrm{K}$ fertiliser application and when to apply the fertiliser.

\section{MATERIALS AND METHODS}

Two field experiments were conducted in 2005 and 2006 wet seasons at the Michael Okpara University of Agriculture, Umudike Teaching and Research farm. Umudike is located at $05^{\circ} 29^{\prime} \mathrm{N}, 07^{\circ} 33^{\prime} \mathrm{E}$ and $122 \mathrm{~m}$ above sea level and situates in the humid tropical lowlands of south eastern Nigeria. The soil of the location is sandy loam and the site is in area of high rainfall with temperatures between 22 and $33^{\circ} \mathrm{C}$ and relative humidity of $75-85 \%$.

The experimental site had been previously under cassava crop but was under a two-year bush fallow prior to land preparation. The experimental site was slashed and land preparation done by conventional tillage with disc plough and later harrowed twice with disc harrow. One meter wide ridges of $3 \mathrm{~m}$ length were prepared. Soil samples from $0-20 \mathrm{~cm}$ depth were collected from different representative locations of the experimental area with soil auger. They were bulked into composite sample, air dried, sieved through a $2 \mathrm{~mm}$ sieve and their physical and chemical properties determined before planting.

Experiments I and II were conducted in 2005 and 2006 wet seasons, respectively during June to October months of the years.

Two Tropical Ipomoea Selection (TIS) sweet potato varieties, TIS $87 / 0087$ and TIS 8164 were used for the experiments. TIS $87 / 0087$ is characterized by trailing vine and light pinkish roots with cream coloured flesh and with rare flowering, while TIS 8164 is characterized by bunchy, erect vine with deep pinkish roots and conspicuous pinkish flowers (Larbi et al., 1997).

The experiment was a $2 \times 4$ factorial in randomised complete block design with four replications in the 2005 cropping season. The plot size was $4 \mathrm{~m} \times 3$ $\mathrm{m}\left(12 \mathrm{~m}^{2}\right)$. The potassium $(\mathrm{K})$ fertiliser treatments were: $0 \mathrm{~kg} \mathrm{~K}, 100 \mathrm{~kg} \mathrm{~K} /$ ha at 4 weeks after planting (WAP), $100 \mathrm{~kg} \mathrm{~K} / \mathrm{ha}$ at $8 \mathrm{WAP}, 20 \mathrm{~kg} \mathrm{k} / \mathrm{ha}$ at $4 \mathrm{WAP}+50 \mathrm{~kg}$ $\mathrm{k} / \mathrm{ha}$ at 8 WAP. The sweet potato treatments were TIS $87 / 0087$ and TIS 8164.

In 2006, a 2 x 8 factorial experiment was conducted using the same sweet potato varieties as in 2005 and the $\mathrm{K}$ treatments were : $0 \mathrm{~kg} \mathrm{~K}, 100 \mathrm{~kg} \mathrm{~K} / \mathrm{ha}$ at $2 \mathrm{WAP}, 100 \mathrm{~kg} \mathrm{~K} / \mathrm{ha}$ at $4 \mathrm{WAP}, 100 \mathrm{~kg} \mathrm{~K} / \mathrm{ha}$ at $6 \mathrm{WAP}$, $100 \mathrm{~kg} \mathrm{~K} / \mathrm{ha}$ at $8 \mathrm{WAP}, 50 \mathrm{~kg} \mathrm{~K} / \mathrm{ha}$ at $2 \mathrm{WAP}+50 \mathrm{~kg}$ $\mathrm{K} / \mathrm{ha}$ at $6 \mathrm{WAP}, 50 \mathrm{~kg} \mathrm{~K} / \mathrm{ha}$ at $2 \mathrm{WAP}+50 \mathrm{~kg} \mathrm{~K} / \mathrm{ha}$ at 8 WAP, $50 \mathrm{~kg} \mathrm{~K} / \mathrm{ha}$ at $4 \mathrm{WAP}+50 \mathrm{~kg} \mathrm{~K} / \mathrm{ha}$ at $8 \mathrm{WAP}$. In each cropping, $\mathrm{K}$ fertiliser was applied as muriate of potash. Each plot received blanket application of $80 \mathrm{~kg}$
(Njoku, 2000) at the initial time of treatment application. Sweet potato vine cuttings of $20 \mathrm{~cm}$ long were planted at a spacing of $1.0 \mathrm{~m} \times 0.3 \mathrm{~m}$ along the crest of the ridge on 18 June, 2005 and on 22 June, 2006. The $1.0 \mathrm{~m} \times 0.3 \mathrm{~m}$ spacing gave a plant population of 33 , 330 plants/ha. Two manual hoe weedings were done at 4 and 8 WAP.

Two plants were randomly selected from the inner rows and tagged and data taken on vine length (longest vine), number of leaves per plant, leaf dry weight, vine dry weight, tuber dry weight and total biomass (total dry matter), all at 10 WAP and 16 WAP. Yield and yield components (number of marketable, unmarketable and total number of tubers $/ \mathrm{m}^{2}$ as well as weight of marketable, unmarketable and total tuber yield/ha) were taken at 16 WAP when the leaves had turned yellowish and had started dropping. Marketable tubers were equal to or greater than $100 \mathrm{~g}$ while unmarketable ones were those that weighed less than $100 \mathrm{~g}$ (Njoku, 2000). Early harvesting was done to avoid Cylas puncticollis damage.

The data for each year were subjected to analysis of variance following the procedures outlined by Gomez and Gomez (1984) and Obi (1986) for a factorial experiment in randomised complete block design with treatment means differences tested for significance using Fisher's protected least significance difference ( $F$ LSD) at $P \leq 0.05)$. The data were analysed using Genstat statistical package (Genstat, 2003).

\section{RESULTS}

The physico-chemical analyses of the soil of the experimental sites were in case sandy loam with low to moderate nutrient contents $(0.07-0.10 \% \mathrm{~N}, 17.4-$ $18.49 \mathrm{mg} / \mathrm{kg} \mathrm{P}$ and $0.11-0.19 \mathrm{mg} / \mathrm{kg} \mathrm{K}$ ) (Table 1).

\section{Growth:}

There were no significant differences $(P>0.05)$ in the number of leaves per plant and vine lengths of TIS 87/0087 and TIS 8164 sweet potato varieties in both 2005 and 2006 cropping seasons (Table 2). Also there was no effect of time of $\mathrm{K}$ application on the number of leaves per plant and vine length in both years, except that in 2006cropping season, the number of leaves was highest with applying all the $\mathrm{K}$ fertilizer at 4 or 6 WAP and lowest with split application at $2+8$ WAP or $4+8$ WAP. Leaf dry weight per plant was not affected by sweet potato variety nor time of $\mathrm{K}$ application in 2005 and 2006. In 2005, tuber and total dry weights as well as harvest index were higher in TIS 87/0087 than TIS 8164 (Table 3). Also in 2006, TIS 87/0087 had higher leaf and vine dry weights but lower harvest index than TIS 8164 .

In 2005, there were no effects of the time of $\mathrm{K}$ application on vine and total dry weights as well as harvest index. In 2006, vine dry weight was higher with application of all the $\mathrm{K}$ fertilizer at 4,6 or 8 WAP or with split application $2+8$ WAP whereas it was least with split application at $2+6$ WAP. The tuber and total dry weights per plant as well as the harvest index were highest with applying half of the $\mathrm{K}$ at 4 WAP and the other half at 8 WAP. The lowest values for tuber and total dry weights as well as $\mathrm{HI}$ were when all the $\mathrm{K}$ was applied at 8 WAP (Table 3). 


\section{Yield and yield components:}

The interaction of sweet potato variety and time of $\mathrm{K}$ application showed that TIS 87/0087 had higher number of marketable and total tubers $/ \mathrm{m}^{2}$ at all $\mathrm{K}$ applications in 2005 (Table 4). However, the number of marketable and total tubers $/ \mathrm{m}^{2}$ were highest with TIS $87 / 0087$ that received all the $100 \mathrm{~kg} \mathrm{~K} / \mathrm{ha}$ fertilizer at 4 WAP. At zero $\mathrm{K}$ and split $\mathrm{K}$ application, TIS $87 / 0087$ had more than one and half times the number of marketable and total number of tubers $/ \mathrm{m}^{2}$ than TIS 8164 variety, especially when all the $K$ was applied at 4 or 8 WAP. Similarly, TIS $87 / 0087$ variety produced the heaviest marketable and total tubers/ $\mathrm{m}^{2}$ when all the $\mathrm{K}$ was applied at 4 WAP (Table 5). In TIS 8164 variety, the weight of marketable tubers and total tubers yield/ha were higher when $\mathrm{K}$ was split applied at $4+8$ WAP than when all the $\mathrm{K}$ was applied at 8 WAP. In TIS 87/0087, there was no effect of time of $\mathrm{K}$ application on tuber yield/ha. Whether $\mathrm{K}$ was applied once or split, TIS times the values, especially when all the $\mathrm{K}$ was applied at 4 or 8 WAP.

In 2006 cropping season, TIS 87/0087 still performed better than TIS 8164 variety for number of marketable and total tubers $/ \mathrm{m}^{2}$ as well as marketable and total tuber yield/ha (Table 6). There was a significant $(P>0.05)$ difference between the two varieties for number of unmarketable tubers $/ \mathrm{m}^{2}$. When all the $\mathrm{K}$ fertiliser was split applied at $2+6$ WAP or $2+8$ WAP, the number of marketable and total tubers $/ \mathrm{m}^{2}$ were higher than whole application at 2, 6 WAP or no application. The time of $\mathrm{K}$ application significantly $(\mathrm{P}<$ 0.05 ) influenced yield and yield components (Table 6). Marketable and total tuber yields were highest with split $\mathrm{K}$ application at $2+6$ WAP or $4+8$ WAP and least with 0 and the whole $100 \mathrm{~kg} \mathrm{k} / \mathrm{ha}$ application at 2 WAP. The result also showed that the total tuber yield was higher in all cases of $\mathrm{K}$ application compared to where $\mathrm{K}$ was not applied.

Table 1: Some physical and chemical characteristics of the soil of the experimental sites in 2005 and 2006 cropping

\begin{tabular}{|c|c|c|}
\hline \multicolumn{3}{|c|}{ seasons } \\
\hline Soil characteristics & 2005 & 2006 \\
\hline \multicolumn{3}{|l|}{ Physical } \\
\hline$\overline{\text { Sand }(\%)}$ & 75.8 & 76.3 \\
\hline Silt (\%) & 3.9 & 3.7 \\
\hline Clay (\%) & 20.3 & 20.1 \\
\hline Textural class & Sandy loam & Sandy loam \\
\hline \multicolumn{3}{|l|}{ Chemical } \\
\hline 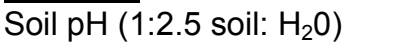 & 4.61 & 4.66 \\
\hline Organic carbon $(\%)$ & 1.17 & 1.23 \\
\hline Organic matter (\%) & 2.98 & 2.22 \\
\hline Total N (\%) & 0.07 & 0.10 \\
\hline Available $P\left(\mathrm{mg} \mathrm{kg}^{-1}\right)$ & 17.4 & 18.49 \\
\hline Exchangeable $\mathrm{K}\left(\mathrm{cmol} \mathrm{kg}^{-1}\right)$ & 0.11 & 0.19 \\
\hline $\mathrm{Ca}\left(\mathrm{cmol} \mathrm{kg}{ }^{-1}\right)$ & 0.50 & 0.48 \\
\hline $\mathrm{Mg}\left(\mathrm{cmol} \mathrm{kg}{ }^{-1}\right)$ & 0.65 & 0.63 \\
\hline
\end{tabular}

Table 2: Number of leaves/plant and vine length $(\mathrm{cm})$ of two sweet potato varieties as influenced by time of $\mathrm{K}$ application at 10 WAP in 2005 and 2006 cropping seasons

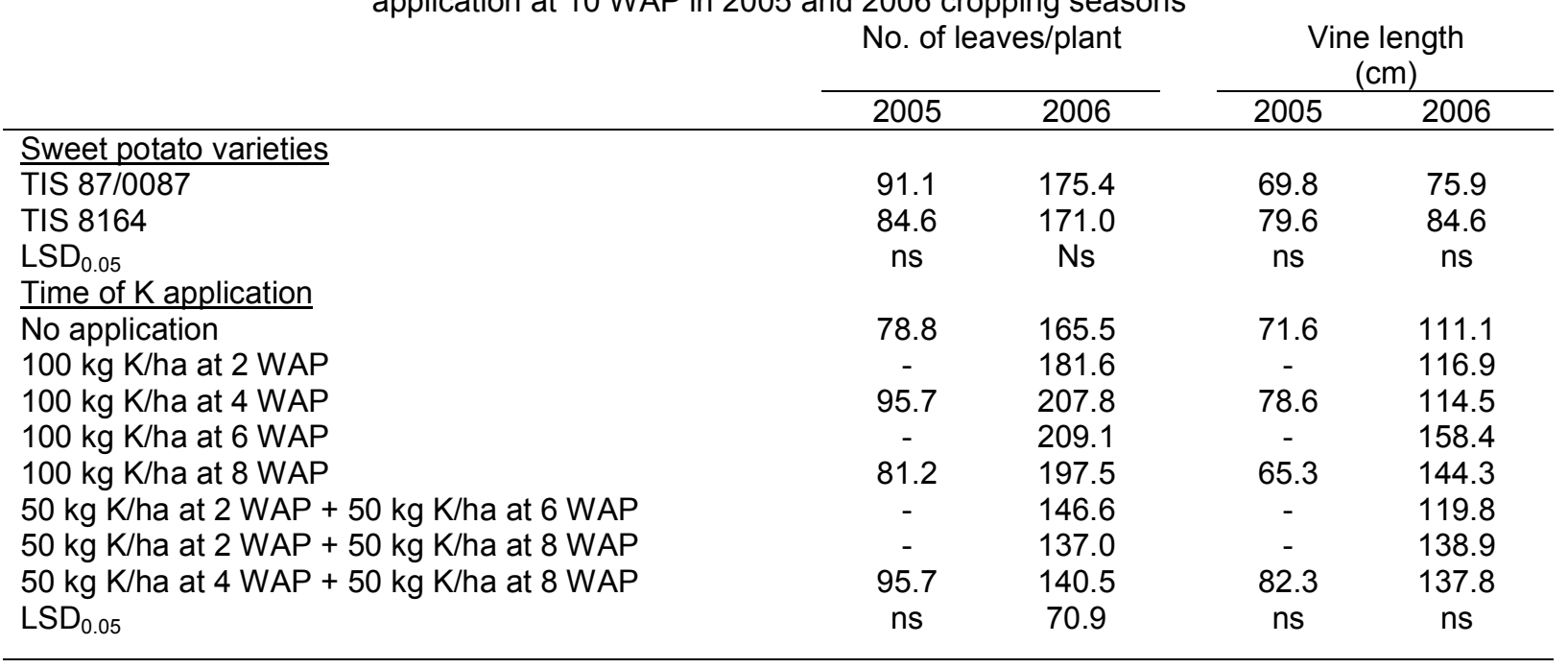


Table 3: Dry matter distribution in tw6 sweet potato varieties as influenced by time of $\mathrm{K}$ application at $10 \mathrm{WAP}$ in 2005 and 2006 cropping seasons

\begin{tabular}{|c|c|c|c|c|c|c|c|c|c|c|}
\hline & \multicolumn{2}{|c|}{$\begin{array}{l}\text { Leaf dry wt } \\
\text { (g/plant) }\end{array}$} & \multicolumn{2}{|c|}{$\begin{array}{l}\text { Vine dry wt } \\
\text { (g/plant) }\end{array}$} & \multicolumn{2}{|c|}{$\begin{array}{c}\text { Tuber dry wt } \\
\text { (g/plant) }\end{array}$} & \multicolumn{2}{|c|}{$\begin{array}{c}\text { Total dry wt } \\
\text { (g/plant) }\end{array}$} & \multicolumn{2}{|c|}{ Harvest index } \\
\hline & 2005 & 2006 & 2005 & 2006 & 2005 & 2006 & 2005 & 2006 & 2005 & 2006 \\
\hline Sweet potato varieties & & & & & & & & & & \\
\hline TIS 87/0087 & 12.1 & 48.8 & 24.5 & 50.5 & 99.3 & 148.0 & 136.3 & 247.3 & 0.68 & 0.55 \\
\hline TIS 8164 & 10.7 & 26.8 & 28.5 & 27.4 & 54.6 & 180.0 & 94.0 & 234.2 & 0.53 & 0.73 \\
\hline $\mathrm{LSD}_{0.05}$ & ns & 13.8 & ns & 8.10 & 35.0 & ns & 42.0 & ns & 0.11 & 0.89 \\
\hline$\frac{\text { Time of } \mathrm{K} \text { application }}{\text { No application }}$ & 117 & 103 & 287 & 317 & 614 & 1050 & 1020 & 1770 & 060 & 0.53 \\
\hline $100 \mathrm{~kg} \mathrm{~K} / \mathrm{h}$ a $2 \mathrm{WAP}$ & - & 34.6 & & 35.4 & - & 167.0 & - & 237.0 & - & 0.70 \\
\hline $100 \mathrm{~kg} \mathrm{~K} / \mathrm{ha}$ at 4 WAP & 9.7 & 31.6 & 24.0 & 44.8 & 91.5 & 171.0 & 125.0 & 247.0 & 0.66 & 0.65 \\
\hline $100 \mathrm{~kg} \mathrm{~K} / \mathrm{ha}$ at 6 WAP & - & 49.6 & & 43.5 & - & 133.0 & - & 227.0 & - & 0.55 \\
\hline $100 \mathrm{~kg} \mathrm{~K} / \mathrm{ha}$ at $8 \mathrm{WAP}$ & 11.9 & 43.7 & 25.5 & 44.7 & 49.7 & 62.0 & 87.0 & 151.0 & 0.54 & 0.41 \\
\hline $50 \mathrm{~kg} \mathrm{~K} / \mathrm{ha}$ at $2 \mathrm{WAP}+50 \mathrm{~kg} \mathrm{~K} / \mathrm{ha}$ at $6 \mathrm{WAP}$ & - & 45.7 & - & 26.9 & - & 222.0 & - & 295.0 & - & 0.76 \\
\hline $50 \mathrm{~kg} \mathrm{~K} / \mathrm{ha}$ at $2 \mathrm{WAP}+50 \mathrm{~kg} \mathrm{~K} / \mathrm{ha}$ at $8 \mathrm{WAP}$ & - & 31.6 & - & 44.8 & - & 198.0 & - & 274.0 & - & 0.72 \\
\hline $50 \mathrm{~kg} \mathrm{~K} / \mathrm{ha}$ at $4 \mathrm{WAP}+50 \mathrm{~kg} \mathrm{~K} / \mathrm{ha}$ at $8 \mathrm{WAP}$ & 12.2 & 25.2 & 28.6 & 39.8 & 105.1 & 248.0 & 146.0 & 311.0 & 0.67 & 0.77 \\
\hline $\operatorname{LSD}_{0.05}$ & ns & ns & ns & 16.4 & 49.5 & 106.0 & ns & 122.0 & ns & 0.18 \\
\hline
\end{tabular}

Table 4: Interaction effects of sweet potato varieties and time of $\mathrm{K}$ application on the marketable and total number of tubers $/ \mathrm{m}^{2}$ in $2005 \mathrm{cropping}$ season

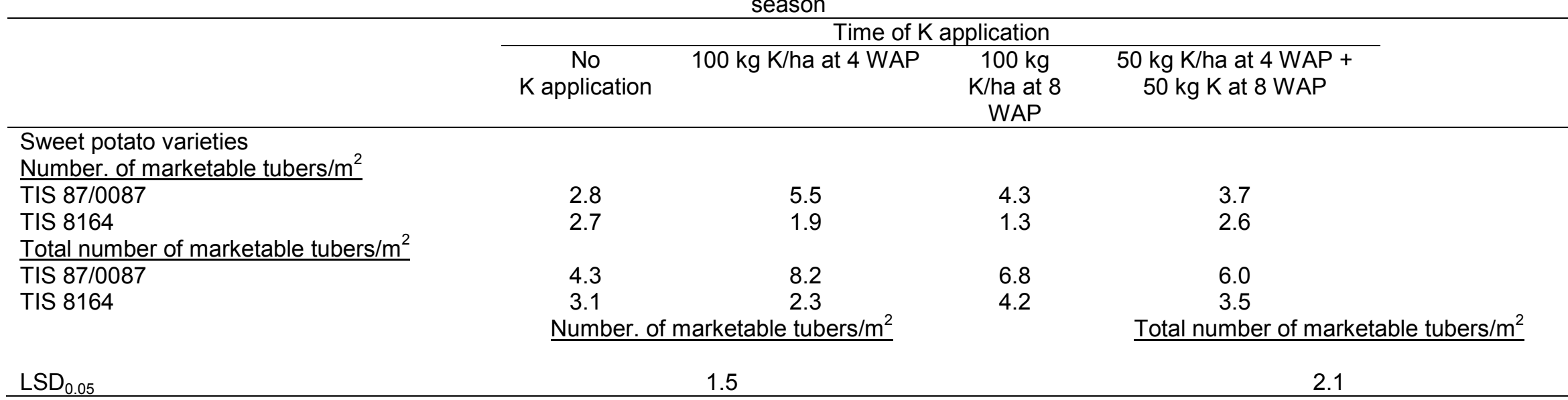


Table 5: Interaction effects of sweet potato varieties and time of $\mathrm{K}$ application on the weight of marketable (t/ha) and total tuber yield (t/ha) in 2005 cropping season

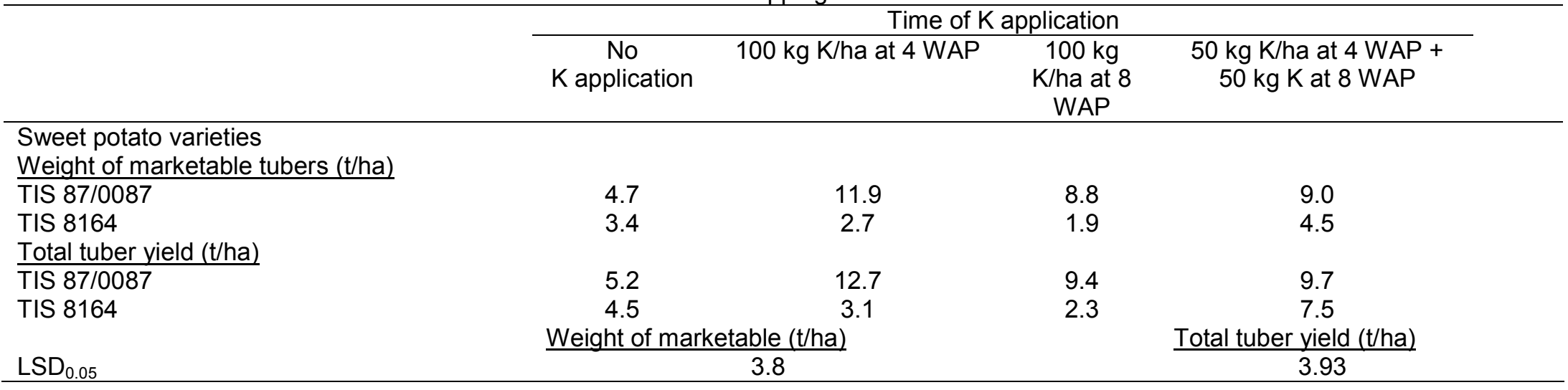

Table 6: Yield and yield components of two sweet potato varieties as influences by time of K application in 2006 cropping season

\begin{tabular}{|c|c|c|c|c|c|}
\hline & $\begin{array}{l}\text { No. of } \\
\text { unmarketable } \\
\text { tubers } / \mathrm{m}^{2}\end{array}$ & $\begin{array}{l}\text { No. of } \\
\text { marketable } \\
\text { tubers } / \mathrm{m}^{2}\end{array}$ & $\begin{array}{l}\text { Total no. of } \\
\text { tubers } / \mathrm{m}^{2}\end{array}$ & $\begin{array}{l}\text { Marketable } \\
\text { tuber yield } \\
\text { (t/ha) }\end{array}$ & $\begin{array}{l}\text { Total } \\
\text { tuber } \\
\text { yield } \\
\text { (t/ha) }\end{array}$ \\
\hline \multicolumn{6}{|l|}{ Sweet potato varieties } \\
\hline TIS 87/0087 & 3.0 & 4.0 & 7.0 & 21.6 & 25.7 \\
\hline TIS 8164 & 2.6 & 3.1 & 5.7 & 12.9 & 17.1 \\
\hline $\begin{array}{l}\mathrm{LSD}_{0.05} \\
\text { Time of K application }\end{array}$ & ns & 0.7 & 1.1 & 3.9 & 4.8 \\
\hline No application & 2.0 & 1.2 & 3.4 & 5.4 & 7.9 \\
\hline $100 \mathrm{~kg} \mathrm{~K} / \mathrm{ha}$ at 2 WAP & 2.0 & 1.8 & 3.8 & 11.4 & 13.4 \\
\hline $100 \mathrm{~kg} \mathrm{~K} / \mathrm{ha}$ at $4 \mathrm{WAP}$ & 3.6 & 3.8 & 7.3 & 19.7 & 22.9 \\
\hline $100 \mathrm{~kg} \mathrm{~K} / \mathrm{ha}$ at $6 \mathrm{WAP}$ & 3.3 & 4.0 & 7.4 & 17.9 & 21.3 \\
\hline $100 \mathrm{~kg} \mathrm{~K} / \mathrm{ha}$ at $8 \mathrm{WAP}$ & 3.4 & 4.0 & 7.4 & 18.8 & 22.6 \\
\hline $\begin{array}{l}50 \mathrm{~kg} \mathrm{~K} / \mathrm{ha} \text { at } 2 \mathrm{WAP}+50 \mathrm{~kg} \mathrm{~K} / \mathrm{ha} \text { at } 6 \\
\text { WAP }\end{array}$ & 2.5 & 4.5 & 7.0 & 25.9 & 30.0 \\
\hline $\begin{array}{l}50 \mathrm{~kg} \mathrm{~K} / \mathrm{ha} \text { at } 2 \mathrm{WAP}+50 \mathrm{~kg} \mathrm{~K} / \mathrm{ha} \text { at } 8 \\
\text { WAP }\end{array}$ & 2.4 & 5.1 & 7.5 & 21.9 & 24.7 \\
\hline $\begin{array}{l}50 \mathrm{~kg} \mathrm{~K} / \mathrm{ha} \text { at } 4 \mathrm{WAP}+50 \mathrm{~kg} \mathrm{~K} / \mathrm{ha} \text { at } 8 \\
\text { WAP }\end{array}$ & 3.3 & 4.1 & 7.5 & 17.2 & 28.2 \\
\hline $\mathrm{LSD}_{0.05}$ & 1.6 & 1.5 & 2.2 & 7.7 & 9.6 \\
\hline
\end{tabular}




\section{DISCUSSION}

The choice of variety and a good fertilizer management programme are important options for ensuring good crop growth and yield (Opara and Asiegbu, 1994: Okpara et al., 2004). TIS 87/0087 sweet potato variety performed better than TIS 8164 probably because of higher leaf, vine, tuber and total dry weights of TIS 87/0087 than those of TIS 9164. Also, the marketable and total number of tubers $/ \mathrm{m}^{2}$ as well as the tuber yield and yield components of TIS 87/0087 variety were higher than those of TIS 8164 at all modes of $\mathrm{K}$ application. In 2005 cropping season, the number of marketable tubers/ was higher in TIS 87/0087 than TIS 8164 by 189,231 or $42 \%$ when $100 \mathrm{~kg} \mathrm{~K} / \mathrm{ha}$ was applied at 4,8 WAP or split application of $\mathrm{K}$ at $4+8$ WAP, respectively. The corresponding values for total number of tubers $/ \mathrm{m}^{2}$ were $256.5,62$ or $71 \%$, respectively. The total tuber yields/ha were higher for TIS $87 / 0087$ by 310 , 309 Or $86.5 \%$ than TIS 8164 with the application of the whole $\mathrm{K}$ at $4,8 \mathrm{WAP}$ or split at $4+8 \mathrm{WAP}$, respectively. In 2006, irrespective of the mode of $\mathrm{K}$ application, TIS $87 / 0087$ variety also performed much better than TIS 8164. The better performance of TIS $87 / 0087$ over TIS 8164 might be due to its better genetic constitution and more vigorous growth (Njoku, 2000). While TIS 87/0087 has trailing habit with its leaves well displayed for photosynthesis and dry matter production, TIS 8164 variety has bunchy habit with most of its leaves being shaded (Larbi et al., 1997). The high yields of TIS $87 / 0087$, which were triple those of TIS 8164 indicated high efficiency and more promising variety. The high total dry matter for TIS 87/0087 could be due to its bulking efficiency and vigorous growth habit. Okwuowulu and Asiegbu (2000), Njoku (2000) and Njoku et al. (2007) also reported the superior performance of TIS $87 / 0087$ compared to other sweet potato varieties.

The need to make soils more productive and sustainable has necessitated judicious use of fertilizers. Advice given to farmers on fertilizer usage has always been based on rates but rarely on time of application, especially with regard to $\mathrm{K}$. The present study was aimed at finding out the mode of application and the best time for this application. It assumed that sweet potato varieties respond to time of $\mathrm{K}$ application. In the work reported here, the sweet potato varieties used yielded higher with split application compared single whole application, especially when $\mathrm{K}$ was split applied at $2+6$ WAP or $4+8$ WAP. The better performance of the varieties with split $\mathrm{K}$ application could be due to nutrient availability all through the crop growth duration and during tuber bulking. Increasing availability of $\mathrm{K}$ had been reported to accelerate the translocation of photosynthates to the tuberous sink with consequent increase in root tuber yield (Hahn, 1977; Obigbesan, 1980; Tsuno, 1981). Other workers had reported better performance of split fertilizer application over single application in other crops such as tomato (Fawusi, 1977; Amans et al., 1996; Oko and Asiegbu, 2001), sugarcane (Ng Kee Kwang and Deville, 1989), rice (Gobi et al., 2006). However, there is controversy with regard to the number of splits to be adopted and the best time to apply the splits (Oko and Asiegbu, 2001). Singh and Singh (1974) were of the view that the number of splits to be adopted depends on the nature of the soil to be of nutrient loss.

In southern Nigeria with its attendant high rainfall and high rates of nutrient loss by leaching during the rainy season, 2 or 3 split applications of fertilizer, especially mobile $\mathrm{N}$ and $\mathrm{K}$ would ensure optimal availability at specific physiological stage of crops and therefore improve yield (Fawusi, 1977). Gobi et al. (2006) suggested up to four splits of $\mathrm{N}$ and $\mathrm{K}$ for rice in India.

The soil of Umudike, Nigeria (the experimental site) has low cation exchange capacity (CEC) and, therefore, has limited capacity to retain the major plant nutrient cations such as $\mathrm{Ca}, \mathrm{Mg}$ and $\mathrm{K}$. This low CEC coupled with high rainfall usually encountered in the area causes extensive leaching of $\mathrm{K}$ and other nutrient cations. This necessitates split application, one at the early growth stage and the others towards the onset of reproductive phase to ensure accumulation of economic yield of the crop.

\section{CONCLUSION}

The TIS $87 / 0087$ which is a higher yielding variety is recommended for the study area with split application of $\mathrm{K}$ at $2 \mathrm{WAP}+6 \mathrm{WAP}$ or at $4 \mathrm{WAP}+8$ WAP. It produced higher marketable and total tuber yields.

\section{REFERENCES}

Amans, E.B., Miko, S., Ibrahim, R., and Erinle, I. D., 1996. Effect of method and time of nitrogen fertilizer application on severity of Sclerotia rofsii attack and fruit yield of tomatoes. In: Adebanjo, A., Adedoyin, F.S. and Alabi, D.A. (Eds.). Proceedings of the Horticultural Society of Nigeria at Ogun State University Ago-Iwoye, Nigeria, 1-4 April, 1996, pp. 66-69.

Ambe-Tumanteh, I., 1994. History and importance of sweet potato in Cameroun. In: Proceedings of the International Potato Centre Workshop in Douala, Cameroun, 27-29 July, 1992, p. 35-46.

Agboola, A.A. and Unamma, R.P.A. 1994. Maintenance of soil fertility under traditional farming system. Proceedings of Natural Organic Fertilizer. Reports of the Progress in Applied Chemistry, 59: 269-290.

CIP, 1980. (International Potato Centre). Sweet potato research in the Peoples Republic of China. CIP/AVRDC/IFPRI study. CIP, Lima.

Edmond, J.B. 1971. Sweet potato production, processing and marketing. Avi Publishers, Westport, Connecticut.

FAO, 2004. (Food and Agricultural Organization). Details of FAO statistics on sweet potato production in West African countries. pp 54-58.

FAO, 2005. (Food and Agricultural Organization). Annual Report. 
Fawusi, M.O.A., 1977. Influence of plant density and time of fertilizer application on growth characteristics, nutrient uptake and yield of tomato. Scientia Horticulturae, 7 (4): 329-337

Genstat, 2003. Genstat 5.0 Release 4.23D discovery edition 1. Lawes Agricultural Trust, Rothamsted Experiment Station.

Gobi, R., Ramesh, S. Pandian, B.J. Chandrasekaran, B. and Sampathkumar, T. 2006. Evaluation of crop split application of $\mathrm{N}$ and $\mathrm{K}$ on growth, yield attributes, yield and economics of hybrid rice $\mathrm{CORH} 2$. Asian Journal of Plant Sciences, 5 (6): 1022-1026.

Gomez, K.A. and Gomez, A.A., 1984. Statistical procedures for agricultural research, $2^{\text {nd }}$ ed., New York, Wiley, 680 pp.

Hahn, S.K., 1977. A quantitative approach to source potentials and sink capacities among reciprocal grafts of sweet potato varieties. Crop Science, 17 (3): $237-246$

Hahn, S.K. and Hozyo, Y. 1984. Sweet potato. In: The physiology of tropical field crops (Eds.) Goldsworth, P.G. and Fisher, N.M., John Wiley and Sons, Chi, Chester, U.K., pp.331-567.

Hahn, S.K. and Hozyo, Y. 1998. Sweet potato reprint series. International Institute of Tropical Agriculture (IITA), Ibadan and Agricultural Research Centre, Yatabe, Tsukebe, Japan, pp. 305-310.

IITA, 1993. (International Institute of Agricultural Research). Annual Report. Farming systems for sustaining farming. p. 14.

Jackson, T.I., Powelson, M.I., Johnson, S.J. and Sullivan, D. 1982. Fertilizer do affect potato diseases. In: Procedings of $21^{\text {st }}$ Washington Potato Conference and Trade Fair, Moses Lake, W.A. 1982, pp. 86-93.

Larbi, A., Nwokocha, H.N., Smith, J.W., Anyanwu, N., Gbarancha, I.D. and Elela, I. 1997. Sweet potato for food and fodder. In: International Livestock Research Institute (ILRI)/National Root Crops Research Institute (NRCRI), Umudike Collaborative Research. Annual Report for 1997.

$\mathrm{Ng} \mathrm{Kee,} \mathrm{K.F.} \mathrm{and} \mathrm{Deville,} \mathrm{J.} \mathrm{1989.} \mathrm{Timing} \mathrm{potassium}$ fertilizer application to sugarcane in Mauritius. Fertilizer research, 20: 153-158.

Njoku, J.C., 2000. Effect $s$ of inorganic nitrogen and potassium on yield and sweet potato in a tropical ultisol. M. Sc. Thesis, Michael Okpara University of Agriculture, Umudike, Nigeria, 46 pp.
Njoku, S.C., Muoneke, C.O., Okpara, D.A. and F.M.O.

Agbo. 2007. Effect of intercropping varieties of sweet potato and okra in an ultisol of south eastern Nigeria. African Journal of Biotechnology, 6 (14): 1650-1654.

NRCRI, 1985. Briefs on other root crops. National Root Crops Research Institute, Umudike, Nigeria Annual Report. p.16.

NRCRI, 2003. (National Root Crops Research Institute), Umudike, Nigeria Annual Report.

Nwinyi, S.C.O., 1987. Sweet potato: A potential industrial and staple food crop of Nigeria. Outlook on Agriculture, 16 (1): 178-181.

Obigbesan, G.O., 1980. Potassium response in root and tuber crops. Paper read at the Potassium Workshop Jointly organized by Internatonal Institute of Tropical Agriculture (IITA) and International Potato Centre (CIP), October 8-10, 1980, Ibadan, Nigeria.

Oko, G.O. and Asiegbu, J.E. 2001. Evaluation of varieties of tomato for yield, quality and optimum time of fertilizer application for a rainy season crop. Proceedings of the $19^{\text {th }}$ Annual Conference of Horticultural Society of Nigeria at the University of Nigeria, Nsukka, May 28-June 1, 2001. pp. 126-129.

Okpara, D.A., Njoku, J.C. and Asiegbu, J.E., 2000. Responses of two sweet potato varieties to four green manure sources and inorganic fertilizer in a humid tropical ultisol. Biological agriculture and horticulture, 22: 81-90.

Okwuowulu, P.A. and Asiegbu, J.E., 2000. Optimum K fertilization and harvest age on four sweet potato (Ipomoea batatas L. Lam) varieties for food tuber yield in tropical ultisol, Nigerian Agricultural Journal, 31: 67-77.

Opara, C.N. and Asiegbu, J.E., 1994. Growth analysis of three West African eggplant genotypes raised under varying regimes of poultry manure treatment. Nigerian Journal of Horticultural Science, 2: 73-81.

Singh, A. and Singh, N.P., 1974, Time and method of fertilizer application under limited availability.

Tsuno, Y., 1981. Sweet potato nutrient, physiology and cultivation, International Potato Centre, Berne, Switzerland.

Udoh, D.J., Ndon, B.A., Asuquo, P.E. and Ndaeyo, N.N., 2005. Crop production techniques for the tropics. Concept Publication Ltd, Lagos, 464 pp.

Woolfe, J.A., 1992. Sweet potato. An untapped resources. Publication in collaboration with the CIP, Cambridge University Press. 